\title{
The Use of Multi-Criteria Decision Approach in Determining the Location for Solid Waste Disposal Facility in Ethiope East, Nigeria
}

\author{
Ochuko Anomohanran ${ }^{1}$ \\ ${ }^{1}$ Physics Department, Delta State University, Abraka, Nigeria \\ Correspondence: Ochuko Anomohanran, Physics Department, Delta State University, Abraka, Delta State, \\ Nigeria. Tel: 2-3480-3948-8655. E-mail: mrochuko@yahoo.com
}

\author{
Received: October 17, 2014 Accepted: November 29, 2014 Online Published: January 19, 2015 \\ doi:10.5539/mas.v9n4p186 URL: http://dx.doi.org/10.5539/mas.v9n4p186
}

\begin{abstract}
This study employed the use of multi-criteria decision approach to identify the most suitable site for a solid waste disposal facility in Ethiope East, Nigeria. Nine decision criteria which were selected based on the characteristics of the area were investigated and ranked for ten different locations. The result of the hydro-geophysical criteria showed that the protective capacity of the aquitard in the survey area ranged from poor to weak. This is an indication that the siting of a solid waste disposal facility in the study area must follow acceptable standards to guide against exposing the groundwater to avoidable pollution. The analysis of the result showed that Samagidi, Isiokoro and Eku ranked highest with a value of 72, 70 and 70 respectively. The result also revealed that Samagidi is the most centralised site among the three locations that ranked highest. Hence it is recommended that a solid waste disposal facility to serve the people of Ethiope East Local Government Area be established in Samagidi.
\end{abstract}

Keywords: waste disposal, multi-criteria decision, landfill, solid waste, protective capacity, Ethiope East

\section{Introduction}

The selection of suitable sites for solid waste disposal is a critical issue in the planning of towns and cities. This is as a result of its serious environmental implication in terms of economy, ecology and environmental health of the people in such an area (Chang et al., 2008). The management of solid waste requires tremendous efforts of the individuals as well as the authorities bestowed with such responsibility. It is a common fact that our towns and cities are overcrowded as a consequence of the dearth of housing infrastructures. This problem has put so much pressure on the available facilities required to effectively handle the waste generated. The challenges posed by the shortage of available facilities have therefore called for the need for city planners to brace up to the challenge of effective management of our waste. (Chang et al., 2008).

Based on the seriousness of this issue, a lot of researchers have carried out studies that will enhance the site selection process for the disposal of solid waste. For instance, Eskandari et al. (2012), Gorsevski et al. (2012), and Gbanie et al. (2013) have all used the multi-criteria decision method and sometimes in conjunction with other techniques to determine the most suitable sites for solid waste disposal. Chang et al. (2008), used the geographic information system with fuzzy method to evaluate landfill site suitability while Khadivi and Ghomi (2012) used the analytical network process and the data envelopment analysis method to determine best location for solid waste disposal. These experts have advocated various ways through which waste could be efficiently managed. This range from reduction of the waste produced, reuse, recycling, energy recovering, incineration and land filling (Eskandari et al., 2012; Gbanie et al., 2013). Despite all of these methods for handling waste, it is impossible to eliminate all forms of waste, hence the best approach to treating waste is by adopting ways that ensure its effect on the environment is brought to the barest minimum.

Solid waste disposal using landfill has been commonly used to managing waste generated from cities and towns. It can however create environmental problem if it is not properly handled or sited (Guiqin et al., 2009). This is the reason why some have considered the method as difficult, complex or tedious (Gbanie et al., 2013; Chang et al., 2008). Landfill is described as a waste disposal method in which waste is spread into thin cells, compressed inside the chamber and covered with a layer of soil. (Gbanie et al., 2013).

Nigeria, like most developing countries of the world is faced with the challenge of dealing with the huge waste 
generated. Facilities deployed to manage the waste generated from various states are grossly insufficient in handling the enormous waste generated. The general practice of handling waste in most areas of the country is through the open dumping method and a few unsanitary landfills. Gorsevski et al. (2012), noted that where they are insufficient infrastructure such as is obtainable in the rural areas of Nigeria, the people dispose their solid waste into the nearest lowland, sometimes by the road side, river bank and sometime directly into the river.

In Nigeria, only very few institutions and local government areas based on their financial position take up the responsibility of building sanitary disposal facility for solid waste. It is therefore important that institutions and the municipal councils saddled with the responsibility of handling waste in Nigeria should pay greater attention in the selection of locations for solid waste disposal. This study is therefore aimed at investigating the possible locations available in Ethiope East Local Government Area using the multi-criteria method and recommends an appropriate location for siting a solid waste disposal facility in the region.

\section{Materials and Methods}

\subsection{Background of the Study Area}

The study area is Ethiope East Local Government Area which is one of the twenty six local government areas in Delta State, Nigeria. It lies within longitude $5.94^{\circ}$ and $6.08^{\circ}$ East and latitude $5.62^{\circ}$ and $5.78^{\circ}$ North (Figure 1). The area is characterised by three stratigraphic formations made up of the Benin, Agbada and Akata Formations. The Benin Formation is the layer of interest in the deployment of solid waste disposal facility. It is made mainly of sand with a pocket of shale making about $5 \%$ of the formation and has a thickness of about $1800 \mathrm{~m}$. Many prolific boreholes have been derived from this formation in this region. The topology of the area is generally flat. The survey area is also characterised by two seasons, namely the wet and dry seasons. These two seasons run for a period of six months each. The means of groundwater recharge in the area are through rain water percolating down the subsurface to the aquifers.

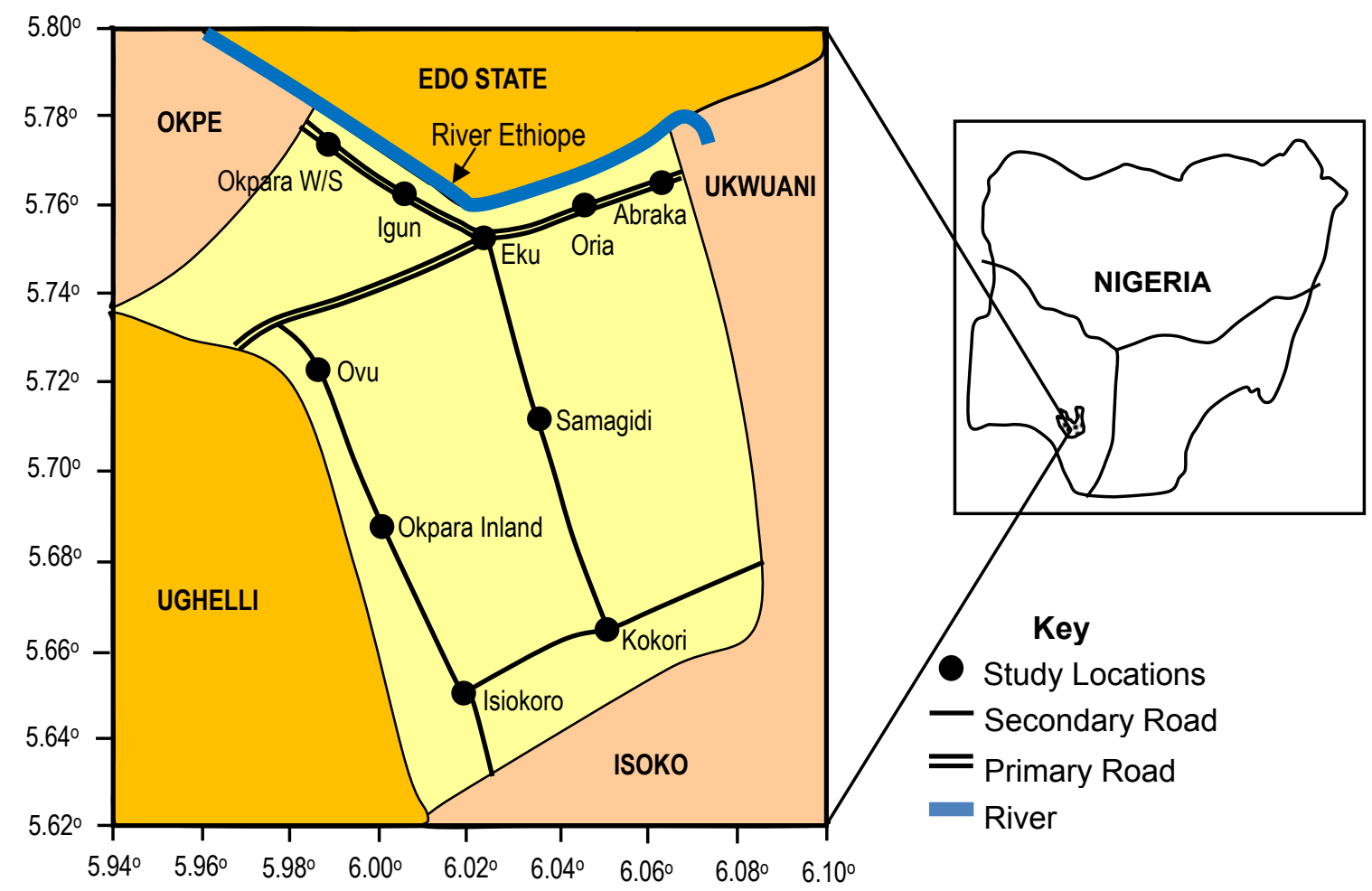

Figure 1. Map of Ethiope East Local Government Area showing the towns selected for this study

\subsection{Data Collection Process}

The site selection process for the establishment of a solid waste disposal facility requires detail evaluation of a number of criteria over a large area to identify the most appropriate location for the facility. These criteria may include hydro-geophysical, geological, political, economic and social. In this study, nine decision criteria were investigated based on the characteristic of the study area. This is to enable the selection of a suitable site for 
which the deployment of a solid waste disposal facility will have the least environmental impact. The following are the criteria investigated.

\subsubsection{Aquifer Protective Capacity}

The choice of a location for the siting of solid waste disposal facilities should be such that the groundwater is well protected from contaminations travelling down the subsurface to pollute the aquifer. In carrying out this investigation, the electrical resistivity method using the vertical electrical sounding technique was employed. Twenty vertical electrical sounding (two at each position) using the Schlumberger configuration in line with the procedure adopted by Anomohanran (2014) was employed. The data obtained were interpreted by curve matching and by computer iteration using Win Resist software. The interpreted data enabled the identification of the aquifer and the aquitard layers. The resistivity and the thickness of the aquitard layer were used to determine the aquitard protective capacity using the relation (Atakpo, 2013):

$$
P=\frac{T}{\rho}
$$

where $\mathrm{P}$ is the protective capacity, $\mathrm{T}$ is the thickness of the confining bed and $\rho$ is the resistivity of the aquitard layer.

The relation in equation 1 was used to evaluate the protective capacity of the ten locations selected for this study and the result was ranked from 1 to 10 with 1 representing the least protected aquifer and 10 the most protected aquifer.

\subsubsection{Distance to Mineral Exploration/Industrial Facilities}

It is established that the siting of a solid waste disposal facility should not be too close to an exploration site or industrial area because of pollution resulting from the facility. A buffer zone of $1 \mathrm{~km}$ is established as a minimum distance of a solid waste disposal facility to any exploration or industrial site (Demesonka et al., 2013). In this survey, $1 \mathrm{~km}$ was also adopted as the minimum distance and is assigned a weight of 1 . Every additional distance of $1 \mathrm{~km}$ attracted an additional 1 point up to a maximum of 10 points. All industrial facilities and exploration sites were identified in the survey area and their distance from the proposed solid waste disposal site were determined and scored.

\subsubsection{Slope}

In the deployment of solid waste facility, the slope plays a very crucial role. It is known to affect the erosion pattern and the runoff rate of the area. If the slope is high, it will impact on the area negatively (Gorsevski, et al., 2012). Higher slope also require considerable cost when constructing a solid waste disposal facility (Gbonie et al., 2013). This is why areas with steep slope are considered inappropriate while areas with gentle slope are considered suitable. Therefore, in this study, a slope of $2^{\circ}$ is considered to be very gentle and is assigned the maximum point of 10 while for every additional $2^{\circ}$, the point reduces by 1 .

\subsubsection{Distance to Surface Water Sources}

The siting of a solid waste disposal facility could pose a big or serious threat to the surface water in the area. This is because, many of our rural dwellers rely on surface water for their daily water needs. Sometimes, the effect is immediate while at other times, it could be long term. This is why it is essential to protect surface water from pollution arising from the solid waste disposal facility. This study, therefore, considered a distance of 0.5 $\mathrm{km}$ as the minimum. This minimum distance attracted a point of 1 while every additional $0.5 \mathrm{~km}$ attracted an additional point.

\subsubsection{Cost of Land}

It is essential that the size of land required for the construction of a solid waste disposal facility should be such that is affordable. In this study, the various locations were categorized in relation to the cost of procuring a 900 sq $\mathrm{m}$ plot of land. A plot of land which cost $\$ 2000$ is ranked 10 points. Every additional increase of $\$ 1000$ reduces the point by 1 .

\subsubsection{Distance to Residential Area}

A solid waste disposal facility is usually located far from residential areas. This is because pollution carried by the wind blowing from the site of the facility could affect the people living in such an area. The residential area occupied by the people needs to be protected from the effect of the waste site. A distance of $1 \mathrm{~km}$ is considered as minimum in line with the work of Gorsevski (2012). This distance is assigned a weight of 1 while every additional $1 \mathrm{~km}$ attracted additional 1 point up to a maximum of 10 points. 


\subsubsection{Distance from Railway}

The distance of the various locations from railway facility was also determined. A distance of $1 \mathrm{~km}$ was taken as the minimum with a weight of 1 assigned to it. Every additional $1 \mathrm{~km}$ from railway facility was given an additional point up to a maximum of 10 .

\subsubsection{Distance to Airport}

The establishment of a solid waste disposal facility should not be too close to an airport. This is because birds which hover around a landfill site could become a disturbing factor to air traffic. A buffer zone of $3 \mathrm{~km}$ is established and used in this study. This distance is assigned 1 while every additional $1 \mathrm{~km}$ attracted an additional 1 point up to a maximum of 10 points.

\subsubsection{Distance to Primary Highway Road}

The distance of solid waste disposal facility to road network is considered very important in the site selection process. Solid waste disposal site is not considered appropriate when located close to a highway or primary road. Facilities which are close to primary road are considered a hindrance to development as they are repellents to tourists. This is why distances which are closer to primary road are scored lower than distances which are far away or located close to secondary roads. A buffer of $0.5 \mathrm{~km}$ from a primary highway is adopted in this study. Every additional $0.5 \mathrm{~km}$ attracted an additional point in the scoring.

Table 1. Result of electrical resistivity interpretation

\begin{tabular}{|c|c|c|c|c|c|c|c|c|}
\hline Locations & $\begin{array}{l}\text { VES } \\
\text { No }\end{array}$ & $\begin{array}{l}\rho_{1} \\
(\Omega \mathrm{m})\end{array}$ & $\begin{array}{l}\rho_{2} \\
(\Omega \mathrm{m})\end{array}$ & $\begin{array}{l}\rho_{3} \\
(\Omega m)\end{array}$ & $\begin{array}{l}\rho_{4} \\
(\Omega \mathrm{m})\end{array}$ & $\begin{array}{l}\mathrm{T}_{1} \\
\text { (m) }\end{array}$ & $\begin{array}{l}T_{2} \\
\text { (m) }\end{array}$ & $\begin{array}{l}T_{3} \\
(m)\end{array}$ \\
\hline \multirow[t]{2}{*}{ Abraka } & 1 & 605 & 322 & 115 & 890 & 0.9 & 9.1 & 3.6 \\
\hline & 2 & 1123 & 687 & 144 & 789 & 1.0 & 8.5 & 4.1 \\
\hline \multirow[t]{2}{*}{ Eku } & 1 & 1334 & 36 & 1954 & 2535 & 0.8 & 2.3 & 20.4 \\
\hline & 2 & 1643 & 45 & 1171 & 2112 & 1.1 & 3.4 & 18.7 \\
\hline \multirow[t]{2}{*}{ Igun } & 1 & 1964 & 57 & 2013 & 2918 & 1.2 & 3.7 & 23.1 \\
\hline & 2 & 1667 & 72 & 1728 & 3227 & 1.1 & 4.1 & 25.7 \\
\hline \multirow[t]{2}{*}{ Isiokoro } & 1 & 952 & 53 & 1384 & 2244 & 2.2 & 3.8 & 12.0 \\
\hline & 2 & 1164 & 64 & 1491 & 2561 & 1.6 & 4.3 & 14.1 \\
\hline \multirow[t]{2}{*}{ Kokori } & 1 & 1210 & 79 & 1515 & 1639 & 1.3 & 2.7 & 13.1 \\
\hline & 2 & 1600 & 73 & 1711 & 2422 & 1.0 & 2.4 & 13.3 \\
\hline \multirow[t]{2}{*}{ Okpara Inland } & 1 & 1506 & 43 & 1193 & 1622 & 1.3 & 3.2 & 14.6 \\
\hline & 2 & 1264 & 101 & 769 & 1694 & 1.6 & 3.8 & 16.1 \\
\hline \multirow[t]{2}{*}{ Okpara Waterside } & 1 & 1234 & 73 & 1162 & 1993 & 1.0 & 2.9 & 17.9 \\
\hline & 2 & 1344 & 99 & 1181 & 1389 & 1.6 & 3.4 & 15.6 \\
\hline \multirow[t]{2}{*}{ Oria } & 1 & 1737 & 64 & 981 & 2153 & 1.0 & 5.6 & 22.5 \\
\hline & 2 & 2101 & 93 & 1162 & 2509 & 0.9 & 4.9 & 24.2 \\
\hline \multirow[t]{2}{*}{ Ovu } & 1 & 1381 & 54 & 1386 & 1543 & 1.1 & 3.9 & 17.2 \\
\hline & 2 & 903 & 69 & 1194 & 1899 & 1.4 & 3.8 & 16.0 \\
\hline \multirow[t]{2}{*}{ Samagidi } & 1 & 591 & 30 & 1029 & 1796 & 1.0 & 2.4 & 19.2 \\
\hline & 2 & 482 & 57 & 1601 & 2597 & 1.2 & 4.9 & 22.0 \\
\hline
\end{tabular}


Table 2. Values obtained from various criteria evaluated

\begin{tabular}{|c|c|c|c|c|c|c|c|c|c|}
\hline \multirow[t]{2}{*}{ Locations } & \multicolumn{9}{|c|}{ Criteria } \\
\hline & $\begin{array}{l}\text { Groundwater } \\
\text { Protective } \\
\text { Capacity }\end{array}$ & $\begin{array}{l}\text { Distance } \\
\text { to } \\
\text { Industrial } \\
\text { Facility } \\
\text { (km) }\end{array}$ & $\begin{array}{l}\text { Slope } \\
\text { (degrees) }\end{array}$ & $\begin{array}{l}\text { Distance } \\
\text { to } \\
\text { Surface } \\
\text { Water } \\
\text { Source } \\
\text { (m) }\end{array}$ & $\begin{array}{l}\text { Cost } \\
\text { of } \\
\text { Land } \\
(\$)\end{array}$ & $\begin{array}{l}\text { Distance to } \\
\text { Residential } \\
\text { Area }(\mathbf{k m})\end{array}$ & $\begin{array}{l}\text { Distance } \\
\text { to } \\
\text { Railway } \\
\text { Facility } \\
\text { (m) }\end{array}$ & $\begin{array}{l}\text { Distance } \\
\text { to } \\
\text { Airport }\end{array}$ & $\begin{array}{l}\text { Distance } \\
\text { to } \\
\text { Primary } \\
\text { Road } \\
\text { Network } \\
\text { (m) }\end{array}$ \\
\hline Abraka & 0.03 & 18 & 10 & 1 & 10000 & 2 & 4 & 38 & 2 \\
\hline Eku & 0.07 & 10 & 4 & 6 & 4000 & 3 & 4 & 28 & 2 \\
\hline Igun & 0.07 & 14 & 4 & 1 & 3000 & 3 & 4 & 33 & 2 \\
\hline Isiokoro & 0.07 & 12 & 6 & 1 & 2000 & 2 & 10 & 29 & 2 \\
\hline Kokori & 0.03 & 12 & 4 & 2 & 2500 & 3 & 13 & 30 & 2 \\
\hline $\begin{array}{l}\text { Okpara } \\
\text { Inland }\end{array}$ & 0.06 & 8 & 2 & 1 & 2000 & 2 & 4 & 21 & 3 \\
\hline $\begin{array}{l}\text { Okpara } \\
\text { Waterside }\end{array}$ & 0.04 & 7 & 2 & 4 & 3000 & 2 & 3 & 24 & 4 \\
\hline Oria & 0.07 & 5 & 2 & 5 & 5000 & 3 & 3 & 30 & 6 \\
\hline Ovu & 0.07 & 1 & 6 & 10 & 5000 & 4 & 3 & 33 & 8 \\
\hline Samagidi & 0.09 & 2 & 6 & 25 & 2000 & 5 & 2 & 33 & 6 \\
\hline
\end{tabular}

Table 3. Ranking of various criteria measured in the study

\begin{tabular}{|c|c|c|c|c|c|c|c|c|c|c|}
\hline \multirow[t]{2}{*}{ Locations } & \multicolumn{10}{|c|}{ Criteria } \\
\hline & $\begin{array}{l}\text { Groundwater } \\
\text { Protective } \\
\text { Capacity }\end{array}$ & $\begin{array}{l}\text { Distance } \\
\text { to } \\
\text { Industrial } \\
\text { Facility } \\
\text { (km) }\end{array}$ & $\begin{array}{l}\text { Slope } \\
\text { (degrees) }\end{array}$ & $\begin{array}{l}\text { Distance } \\
\text { to } \\
\text { Surface } \\
\text { Water } \\
\text { Source } \\
\text { (m) }\end{array}$ & $\begin{array}{l}\text { Cost } \\
\text { of } \\
\text { Land } \\
\text { (\$) }\end{array}$ & $\begin{array}{l}\text { Distance to } \\
\text { Residential } \\
\text { Area }(\mathbf{k m})\end{array}$ & $\begin{array}{l}\text { Distance } \\
\text { to } \\
\text { Railway } \\
\text { Facility } \\
\text { (m) }\end{array}$ & $\begin{array}{l}\text { Distance } \\
\text { to } \\
\text { Airport }\end{array}$ & $\begin{array}{l}\text { Distance } \\
\text { to } \\
\text { Primary } \\
\text { Road } \\
\text { Network } \\
\text { (m) }\end{array}$ & $\begin{array}{l}\text { Total } \\
\text { Points }\end{array}$ \\
\hline Abraka & 1 & 10 & 6 & 2 & 2 & 4 & 4 & 10 & 4 & 43 \\
\hline Eku & 9 & 10 & 9 & 10 & 8 & 6 & 4 & 10 & 4 & 70 \\
\hline Igun & 9 & 10 & 9 & 2 & 9 & 6 & 4 & 10 & 4 & 63 \\
\hline Isiokoro & 9 & 10 & 8 & 2 & 10 & 4 & 10 & 10 & 4 & 67 \\
\hline Kokori & 1 & 10 & 9 & 4 & 10 & 6 & 10 & 10 & 4 & 64 \\
\hline $\begin{array}{l}\text { Okpara } \\
\text { Inland }\end{array}$ & 4 & 8 & 10 & 2 & 10 & 4 & 4 & 10 & 6 & 58 \\
\hline $\begin{array}{l}\text { Okpara } \\
\text { Waterside }\end{array}$ & 3 & 7 & 10 & 8 & 9 & 4 & 3 & 10 & 8 & 62 \\
\hline Oria & 9 & 5 & 10 & 10 & 7 & 6 & 3 & 10 & 10 & 70 \\
\hline Ovu & 9 & 1 & 8 & 10 & 7 & 8 & 3 & 10 & 10 & 66 \\
\hline Samagidi & 10 & 2 & 8 & 10 & 10 & 10 & 2 & 10 & 10 & 72 \\
\hline
\end{tabular}

\section{Results and Discussion}

The result of the quantitative interpretation of the geoelectric data acquired to determine the protective layers of the subsurface in the ten locations is presented as shown in Table 1. Table 1 indicates that the area is marked mainly of four stratigraphic layers. The protective layer in Abraka is the third, while the other locations had their 
protective layer as the second formation. The resistivity values of the protective layers ranged from $30 \Omega \mathrm{m}$ in Samagidi to $144 \Omega \mathrm{m}$ in Abraka. The thickness ranged from $2.3 \mathrm{~m}$ in Eku to $5.6 \mathrm{~m}$ in Oria. The values of the resistivity and the thickness of the protective layers were substituted into equation 1 to determine the protective capacity of the groundwater aquifer in all the locations investigated. The protective capacity of the study area ranged from 0.03 in Abraka to 0.09 in Samagidi. The effect of this is that the protective capacity of the groundwater aquifer ranged from poor to week. The evaluated values together with the measurement of the other criteria determined were presented as shown in Table 2. Table 2 also shows that Abraka has the longest distance from industrial facilities in the area while Kokori is the closest location to industrial site because it harbour an oil flow station. Table 2 also shows that the area has a gentle slope with Abraka having the highest slope value of $10^{\circ}$ while Okpara Inland, Okpara Water Side and Ovu have the minimum value of $2^{\circ}$. The study area as is seen from Figure 1 has a major river known as Ethiope River and also small streams close to Ovu. The distance from the stream or river to the proposed waste disposal site is also shown in the table. Table 2 further shows that the cost of land is highest in Abraka with a value of $\$ 10,000$ for a plot of land measuring $900 \mathrm{sq} \mathrm{m}$. The lowest cost is obtained from locations such as Isokoro, Okpara Inland and Samagidi which cost \$2000 per plot. Other measurements shown in Table 2 are the distances to railway, airport and the primary road network.

All the criteria measured were assigned weights between 1 and 10 and the result of the ranking presented as shown in Table 3. The result presented in Table 3 shows that the most suitable location to site the solid waste disposal facility is Samagidi having a total score of 72 points. This is followed by Isiokoro and Eku scoring a total of 70 points each. The lowest score was obtained from Abraka with a value of 43 points. This implies that Abraka is the last site to consider when deploying a solid waste facility in the area as it has the highest possibility of being seriously affected by the effect of the facility. Abraka is closely followed from the bottom of the ladder by Okpara Inland and Okpara Waterside with a value of 58 and 62 points respectively.

The result of this study has therefore shown that a solid waste disposal facility can be deployed in Samagidi with minimum environmental impart. This location as is seen from Figure 2 also has the advantage of being the most centralised site among the locations investigated. This implies that it will be more economical in terms of transporting the waste from the various locations where they are generated to the waste facility.

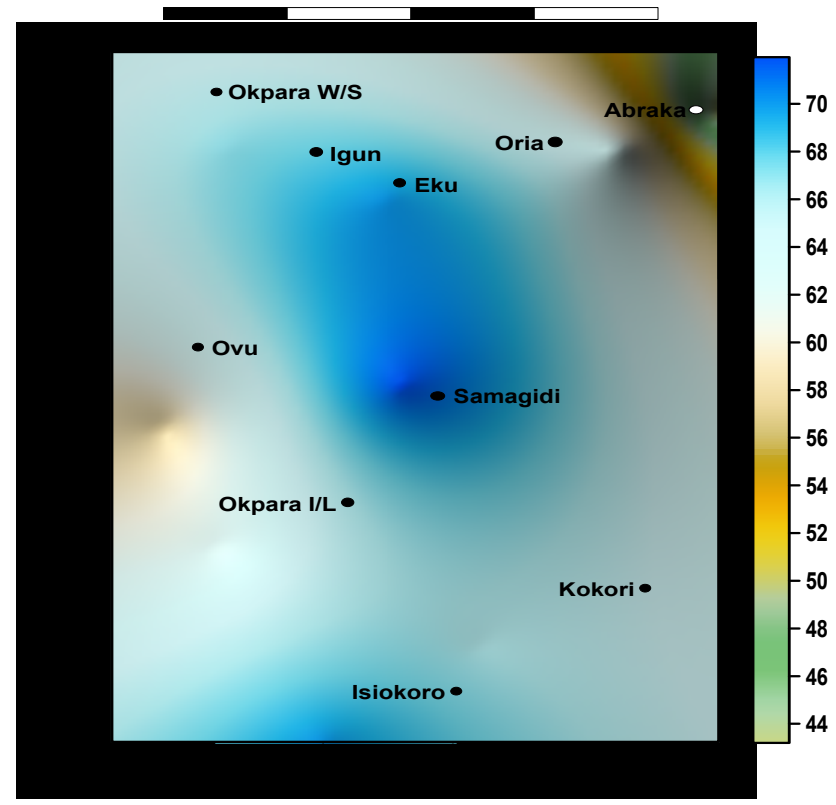

Figure 2. Suitability map showing that Samagidi is the most suitable location for siting a solid waste disposal facility

\section{Conclusion}

This study to identify the most suitable location for a solid waste disposal facility has been carried out using various decision criteria which include geophysical, geological, social and economical. The study was carried out in ten different locations. The results obtained from the various criteria evaluated were ranked and the result showed that Samagidi with a weighted value of 72 points is the most suitable site to deploy solid waste disposal 
facility in the area. This site also has the advantage of being the most centralised site among the locations investigated. It is therefore recommended that a solid waste facility to serve the people of Ethiope East Local Government Area be established in Samagidi.

\section{References}

Anomohanran, O. (2014). Hydrogeophysical and hydrogeological investigations of groundwater resources in Delta Central, Nigeria. Journal of Taibah University for Science, 9(1), 57-68. http://dx.doi.org/10.1016/j.jtusci.2014.06.003

Atakpo, E. A. (2013). Aquifer vulnerability investigation using geoelectric method in parts of Sapele Local Government Area of Delta State, Nigeria. Nigerian Journal of Basic and Applied Science, 21(1), 11-19.

Chang, N., Parvathinathan, G., \& Breeden, J. B. (2008). Combining GIS with fuzzy multicriteria decision making for landfill siting in a fast-growing urban region, Journal of Environmental Management, 87, 139-153. http://dx.doi.org/10.1016/j.jenvman.2007.01.011

Demesouka, O. E., Vavatsikos, A. P., \& Anagnostopoulos, K. P. (2013). Suitability analysis for siting MSW landfills and its multicriteria spatial decision support system: Method, implementation and case study, Waste Management, 33, 1190-1206. http://dx.doi.org/10.1016/j.wasman.2013.01.030

Eskandari, M., Homaee, M., \& Mahmodi, S. (2012). An integrated multi criteria approach for landfill siting in a conflicting environmental, economical and socio-cultural area, Waste Management, 32, 1528-1538. http://dx.doi.org/10.1016/j.wasman.2012.03.014

Gbanie, S. P., Tengbe, P. B., Momoh, J. S., \& Medo, J. (2013). Modelling landfill location using Geographic Information System (GIS) and Multi-Criteria Decision Analysis (MCDA): Case study Bo, Southern Sierra Leone, Applied Geography, 36, 3-12. http://dx.doi.org/10.1016/j.apgeog.2012.06.013

Gorsevski, P. V., Donevska, K. R., Mitrovski, C. D., \& Frizado, J. P. (2012). Integrating multi-criteria evaluation techniques with geographic information system for landfill site selection: A case study using ordered weighted average, Waste Management, 32, 287-296. http://dx.doi.org/10.1016/j.wasman.2011.09.023

Guiqin, W., Li, Q., Guozue, L., \& Lijun, C. (2009). Landfill site selection using spatial information technologies and AHP: A case study in Beijing, China, Journal of Environmental Management, 90, 2414-2421. http://dx.doi.org/10.1016/j.jenvman.2008.12.008

Khadivi, M. R., \& Fatemi Ghomi, S. M. T. (2012). Solid waste facilities location using of analytical network process and data envelopment analysis approaches, Waste Management, 32, 1258-1265. http://dx.doi.org/10.1016/j.wasman.2012.02.002

\section{Copyrights}

Copyright for this article is retained by the author(s), with first publication rights granted to the journal.

This is an open-access article distributed under the terms and conditions of the Creative Commons Attribution license (http://creativecommons.org/licenses/by/3.0/). 